\title{
Xác định tên khoa học của cây Ô đầu bằng phương pháp giải trình tự gen $\mathrm{ADN}$
}

\author{
Bùi Thanh Tùng ${ }^{1}$, Nguyễn Tiến Vững ${ }^{2}$, Vũ Đức Lợi ${ }^{1, *}$ \\ ${ }^{1}$ Khoa Y Duợc, Đại học Quốc gia Hà Nội, 144 Xuân Thủy, Cầu Giấy, Hà Nội, Việt Nam \\ ${ }^{2}$ Viện Pháp y Quốc gia, số 41 Nguyễn Đình Chiểu, Hai Bà Trung, Hà Nội, Việt Nam \\ Nhận ngày 26 tháng 8 năm 2016 \\ Chỉnh sửa ngày 06 tháng 10 năm 2016; Chấp nhận đăng ngày 14 tháng 6 năm 2017
}

Tóm tắt: Từ mẫu lá cây ô đầu trồng ở tỉnh Hà Giang, đã chiết tách, phân tích, giải trình tự gen và so sánh với mẫu trình tự gen của loài thuộc chi Aconitum. Kết quả đã giải được trình tự gen của cây Ô đầu và khi so sánh với trình tự gen của loài $A$. carmichaeli Debx. thấy có sự tương đồng đến $99 \%$. Như vậy bằng phương pháp giải trình tự gen $\mathrm{ADN}$ đã xác định được tên khoa học của cây $\mathrm{O}$ đầu trồng ở tỉnh Hà Giang là: $A$. carmichaeli Debx. họ Ranunculaceae.

Tù khóa: Ô đầu, trình tự gen, ADN.

\section{1. Đặt vấn đề}

Cây Ô đầu thuộc chi Aconitum, đây là một chi lớn với hơn 500 loài đã được ghi nhận trên thế giới. Theo một tài liệu, cây Ô đầu ở Việt Nam được cho là có nguồn gốc từ Trung Quốc, di thực vào Việt Nam từ những năm 70 thế kỷ trước. Tuy nhiên, tên khoa học cây Ô đầu trồng ở Việt Nam ghi nhận dưới 2 tên là: $A$. carmichaeli Debx. và $A$. fortunei Hemsl $[1,2]$. Để xác định tên khoa học của một loài cây, có thể thông qua phân tích đặc điểm hình thái, so sánh với khóa phân loại thực vật hoặc phân tích mã gen $\mathrm{ADN}$ và so sánh với gen $\mathrm{ADN}$ gốc trong ngân hàng gen. Bài báo này công bố kết quả giải trình tự gen $\mathrm{ADN}$ của cây Ố đầu trồng ở tỉnh Hà Giang qua đó xác định tên khoa học của cây này.

\section{Nguyên liệu và phương pháp}

\subsection{Nguyên liệu}

\footnotetext{
* Tác giả liên hệ. ĐT.: 84-989313325.

Email: ducloi82@gmail.com

https://doi.org/10.25073/2588-1132/vnumps.4053
}

+ Lấy mẫu lá non tươi của cây ô đầu để chiết và phân tích $A D N$, giải trình tự gen, so sánh với mẫu trình tự gen của loài thuộc chi Aconitum

+ Hóa chất: đệm tách ADN

+ Thiết bị phân tách $\mathrm{ADN}$ điện di bằng bản gel agarose, thiết bị giải trình tự gen tự động Nextseq 500.

\subsection{Phuoong pháp nghiên cứu}

* Tách chiết ADN tổng số:

$\mathrm{ADN}$ toàn phần được tách từ lá tươi theo quy trình tách chiết $\mathrm{ADN}$ DNeasy plant mini kits (QIAGEN, USA). ADN toàn phần được kiểm tra lại bằng phương pháp điện di trên gel agarose [3].

* Khuếch đại $\mathrm{ADN}$ bằng $\mathrm{PCR}$ :

Đoạn trình tự ADN mARN ITS1-5,8S-ITS2 được khuếch đại sử dụng cặp mồi ITS5: 5' GGAAGTAAAAGTCGTAACAAGG-3' và ITS4: 5'- TCCTCCGCTTATTGATATGC-3' 


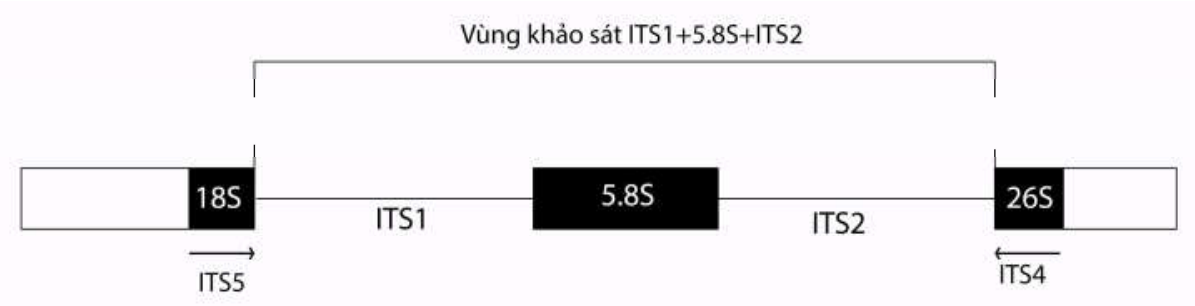

Hình 1. Vùng gen khảo sát ITS1-5,8S-ITS2.

Chu trình nhiêt cho môt phản úng PCR $d u$ kiến: Khởi động nhiệt $94{ }^{\circ} \mathrm{C}$ trong 3 phút.Tiến hành 35 chu kỳ (Biến tính: $94{ }^{\circ} \mathrm{C}$ trong 1 phút + Bắt cặp: $54{ }^{\circ} \mathrm{C}$ trong 1 phút + Khuếch đại: 72 ${ }^{\circ} \mathrm{C}$ trong 1 phút). Pha tổng hợp cuối cùng: $72{ }^{\circ} \mathrm{C}$ trong 8 phút.

* Điện di ADN trên gel agarose

Nguyên tắc: Các đoạn $\mathrm{ADN}$ mang điện tích âm nên di chuyển trong điện trường theo chiều từ cực âm sang cực dương. Trên bản gel agarose, các đoạn ADN có kích thước khác nhau sẽ di chuyển với tốc độ khác nhau trong điện trường. Nhuộm $\mathrm{ADN}$ bằng Ethidium bromid để quan sát $\mathrm{ADN}$ dưới ánh sáng tử ngoại, bước sóng $254 \mathrm{~nm}$.

Tiến hành: Đặt bản gel agarose vào trong máy điện di có dung dịch đệm TAE $1 \mathrm{X}$, tra mẫu $\mathrm{ADN}$ cùng với chất chỉ thị xanh bromophenol vào giếng trên bản gel. Chạy điện di ở điện thế $110 \mathrm{~V}$. Sau đó nhuộm bản gel bằng Ethidium bromid, rửa sạch bằng nước cất rồi quan sát dưới đèn tử ngoại ở bước sóng $254 \mathrm{~nm}$.

* Phương pháp tinh sạch ADN

Để tinh sạch ADN, sử dụng kit tinh sạch của hãng Fermentas (Đức) gồm các bước tiến hành như sau:

1. Lấy $100 \mu \mathrm{L}$ đệm tách $\mathrm{ADN}$, cùng với $100 \mu \mathrm{L}$ ADN rồi trộn đều.

2. Chuyển lên cột Genne $\mathrm{Jet}^{\mathrm{Tm}}$. Sau đó ly tâm với tốc độ 12.000 vòng/phút trong 1 phút, bỏ phần dịch bên dưới

3. Thêm $700 \mu \mathrm{L}$ đệm rửa để loại tạp chất. Sau đó ly tâm với tốc độ 12.000 vòng/phút trong 2 phút, bỏ phần dịch bên dưới.

4. Đặt cột vào trong ống $1,5 \mu \mathrm{L}$. Cho $30 \mu \mathrm{L}$ $\mathrm{H}_{2} \mathrm{O}$ vào cột sau đó ly tâm với tốc độ 12.000 vòng/phút trong 2 phút.

5. Bảo quản $\mathrm{ADN}$ ở -20 đến $-80^{\circ} \mathrm{C}$
* Phương pháp giải trình tự

Nguyên tắc: Dựa theo phương pháp Sanger cải tiến có sử dụng các dideoxynucleotid. Mỗi loại dideoxynucleotid được đánh dấu bằng chất huỳnh quang có màu khác nhau. Nhờ vậy tất cả các oligonucleotid cùng chấm dứt tại một dideoxynucleotid sẽ có cùng một màu. Trình tự $\mathrm{ADN}$ được giải trình tự bởi công ty Macrogen (Hàn Quốc) trên máy đọc trình tự tự động.

* So sánh trình tự ADN

Trình tự $\mathrm{ADN}$ của các mẫu được phân tích bằng phần mềm MEGA 6,0 và so sánh với ADN của loài thuộc chi Aconitum đã công bố trên ngân hàng gen bằng công cụ NCBI/BLAST, công cụ này sẽ chỉ ra độ tương đồng của các gen giữa loài nghiên cứu với các công bố trước đây [6].

\section{Kết quả và bàn luận}

Mẫu lá tươi cây ô đầu được chiết xuất, phân tách $\mathrm{ADN}$, giải trình tự gen, so sánh với mẫu trình tự gen đã công bố của các loài thuộc chi Aconitum cho kết quả như sau:

* Tách chiết ADN tổng số và thực hiện phản ứng nhân gen PCR:

ADN tổng số sau khi tách được điện di trên gel agarose $1 \%$ cho vạch ADN rõ, băng điện di sạch, không lẫn $\mathrm{ARN}$. ADN tổng số sau khi thực hiện phản ứng nhân gen với đoạn ITS15,8S-ITS2 được điện di so sánh với thang ladder chuẩn 100 bps, cho thấy kích thước đoạn trình tự thu được vào khoảng hơn $600 \mathrm{bps}$. Vạch sản phẩm trên băng điện di đậm, rõ nét nên đủ điều kiện để tiếp tục tinh sạch để thực hiện phản ứng giải trình tự. 


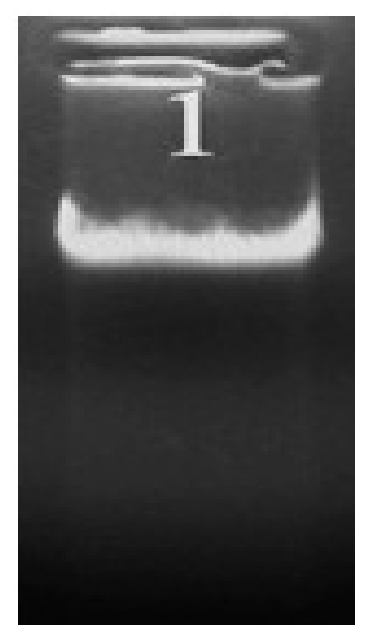

Hình 2. Điện di ADN tổng số.

* Trình tự đoạn gen ITS1-5,8S-ITS2:

Trình tự $\mathrm{ADN}$ sau khi giải trình tự thu được gồm 640 bps trong đó có 609 bps hiện rõ, được đưa vào để so sánh với trình tự công bố, trong đó tỷ lệ G-C là $62,3 \%$, tỷ lệ A-T là $37,7 \%$. Công cụ NCBI/Blast được sử dụng để so sánh

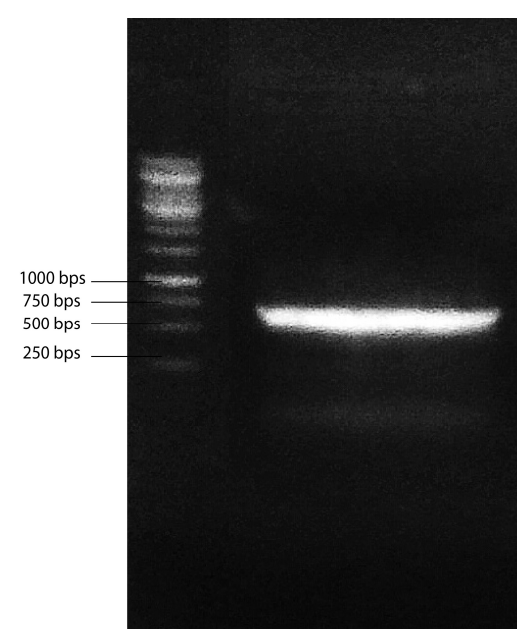

Hình 3. Điện di sản phẩm PCR.

với trình tự đã công bố trên ngân hàng gen thế giới (mã hiệu ngân hàng gen: FJ424223) cho thấy trình tự gen thu được tương đồng với trình tự loài $A$. carmichaeli Debx. đã công bố với số nucleotid tương đồng là 606/609 (tương ứng tỷ lệ tương đồng 99\%).

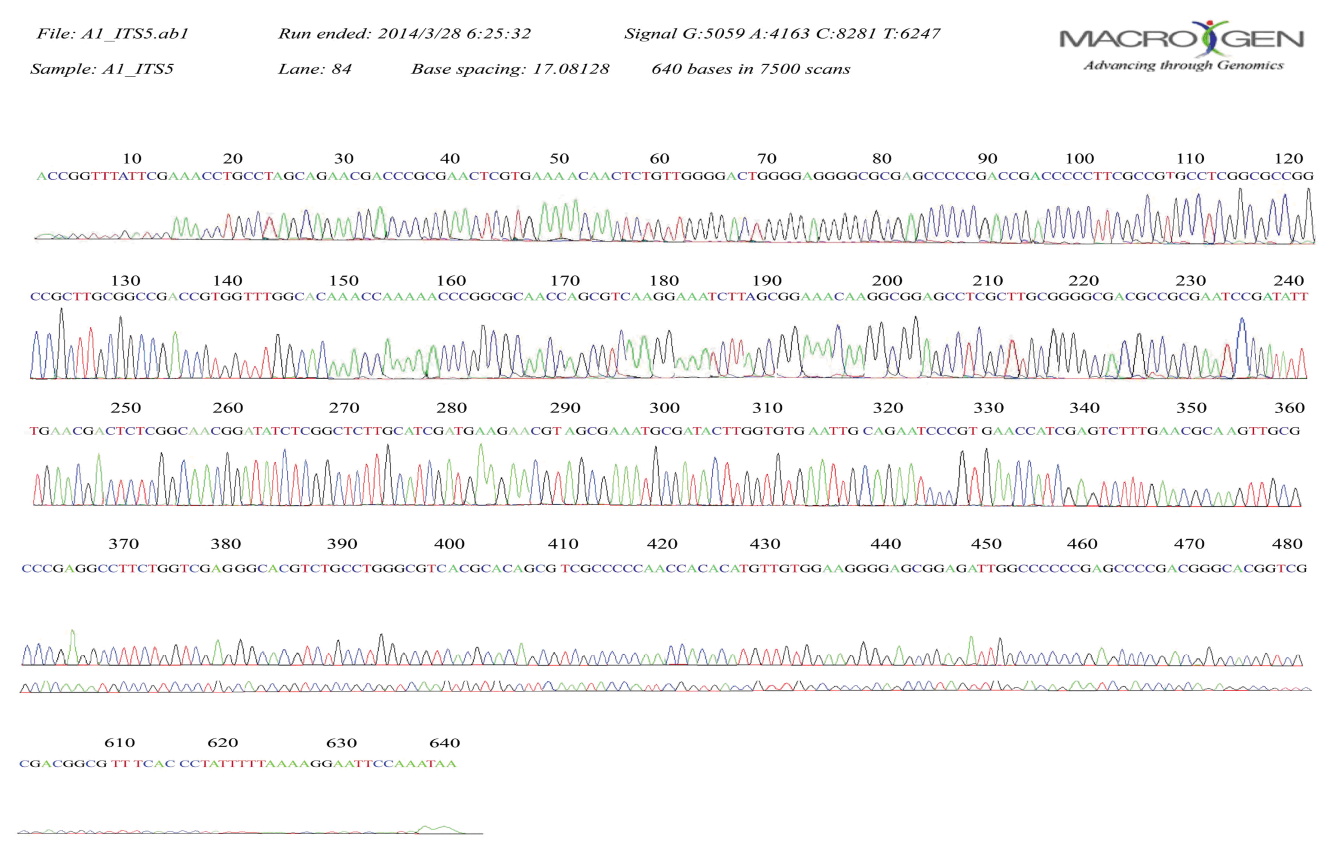

Hình 4. Kết quả giải trình tự gen $\mathrm{ADN}$. 


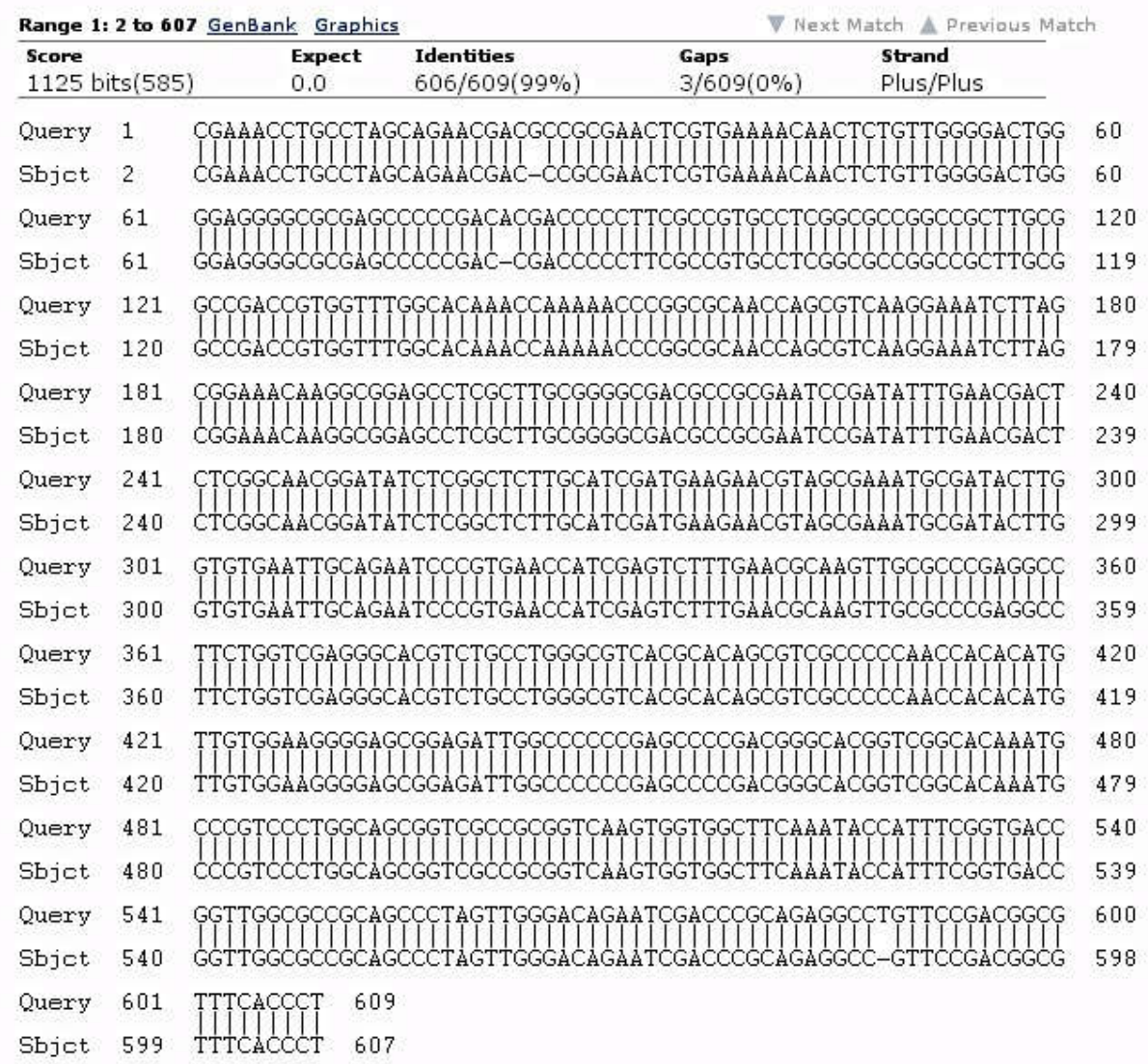

Hình 5. So sánh trình tự đoạn gen ITS1-5,8S- ITS2 của mẫu nghiên cứu với trình tự loài đã công bố trên thế giới.

Trong đó: Query là trình tự mẫu nghiên cứu và Sbjct là trình tự loài $A$. carmichaeli Debx. đã công bố trên ngân hàng gen thế giới (mã hiệu ngân hàng gen: FJ424223) $[4,6]$.

Kết quả giải trình tự gen và so sánh trình tự gen của cây Ô đầu trồng ở tỉnh Hà Giang với trình tự gen loài là $A$. carmichaeli Debx. là cơ sở tin cậy để khẳng định tên khoa học của cây Ô đầu trồng ở tỉnh Hà Giang là: Aconitum carmichaeli Debx. Họ Ranunculaceae.

\section{Bàn luận}

Chi Aconitum là một chi lớn thuộc họ Ranunculacae với khoảng 331 loài, đặc điểm thực vật giữa các loài khác nhau ở một số điểm nhất định. Chi này phân bố ở khu vực phía bắc ôn đới, khu vực lạnh ở bán cầu bắc, chủ yếu ở vùng núi Đông Á, Đông Nam Á, Trung Âu, một số ở phía tây bắc Mỹ. Ở Việt Nam cũng ghi nhận cây Ô đầu có ở một số tỉnh vùng núi cao, khí hậu lạnh mát như: Hà Giang, Lào Cai, Lai Châu, Cao Bằng. Hiện nay trên thế giới, chi Aconitum ghi nhận có khoảng 948 loài nhưng số loài được chấp nhận chỉ có khoảng 331 loài [5]. Do các loài thuộc chi Aconitum được đặt tên khác nhau và trước kia không công bố rộng rãi nên một loài lại có thể có nhiều tên khác nhau. Mặt khác căn cứ vào đặc điểm thực vật để phân loại cũng khó khăn, do đặc điểm giữa các loài khác nhau không nhiều, cùng một loài sống trong các điều kiện khác nhau, có thể có sự thay đổi về hình thái.

Mặt khác, một số nước như Trung Quốc, Hàn Quốc đã xây dựng cơ sở dữ liệu về $\mathrm{ADN}$ 
của các loài thuộc chi Aconitum. Để góp phần khẳng định tên khoa học của cây Ô đầu trồng ở tỉnh Hà Giang, ngoài phương pháp phân tích đặc điểm hình thái thực vật, chúng tôi tiến hành giám định $\mathrm{ADN}$ của mẫu cây này. Đối với cây Ô đầu trồng ở Việt Nam đây là lần đầu tiên, phương pháp giám định $\mathrm{ADN}$ được sử dụng để giám định tên khoa học của cây. Sau khi chiết xuất, phân tách $\mathrm{ADN}$ và giải trình tự gen của mẫu lá cây Ô đầu, cho kết quả trình tự gen. So sánh trình tự đoạn gen ITS1-5,8S- ITS2 này với trình tự gen đã công bố của loài $A$. carmichaeli Debx [4]. cho thấy có sự trùng khớp nhau đến 99 $\%$. Theo tác giả của công trình nghiên cứu về xác định tên các loài Aconitum bằng $\mathrm{ADN}$, đây là phương pháp có độ tin cậy, tính chọn lọc cao.

\section{Kết luận}

Đây là lần đầu tiên, trình tự gen cây Ô đầu tại Việt Nam được nghiên cứu và công bố. Nghiên cứu này đã góp phần đưa ra cơ sở khoa học về tên loài cây Ô đầu trồng ở tỉnh Hà Giang. Bằng phương pháp giám định $\mathrm{ADN}$, khẳng định tên khoa học của cây Ô đầu trồng ở tỉnh Hà Giang là: A. carmichaeli Debx. họ Ranunculaceae.

\section{Tài liệu tham khảo}

[1] Nguyễn Tiến Bân (Chủ biên) (2013), Danh lục các loài thực vật Việt Nam, Nxb Nông nghiệp, Hà Nội, tập II, tr.153.

[2] Bộ Y tế (2009), Dược điển Việt Nam IV, Nxb Y học, tr. 857-858, 860-862

[3] Doyle J.J., Doyle J.L. (1990), "Isolation of Plant DNA from fresh tissue", Focu, 12(6), $13-15$.

[4] Jun H., Ka-Lok W., Pang-Chui S. (2010), "Identification of the Medicinal Plants in Aconitum L. by DNA Barcoding Technique" Planta Medica, 76(8), 1622-1628.

[5] Neelofar J., Mohammad I. K., Ghulam H. D., Abdul S. S. K. (2012), "Distribution and Taxonomy of Genus Aconitum in Kashmir: Potent Medicinal Resource of Himalayan", Chiang Mai Journal Sciences, 40(2), 173 - 186.

[6] Zheng Z., Stephen F. A., Thomas L. M., Alejandro A. S., Jinghui Z., Webb M., and David J. L. (1997), "Gapped blast and psi-blast: a new generation of protein database search programs", Nucleic Acids Reserch, 25(6), 3389-3402.

\title{
Determined the Scientific Name of the A. carmichaeli Debx. by Method of DNA Sequencing
}

\author{
Bui Thanh Tung ${ }^{1}$, Nguyen Tien Vung ${ }^{2}$, Vu Duc Loi ${ }^{1}$ \\ ${ }^{I}$ VNU School of Medicine and Pharmacy, 144 Xuan Thuy, Cau Giay, Hanoi, Vietnam \\ ${ }^{2}$ National Institute of Forensic Medicine, 41 Nguyen Dinh Chieu, Hai Ba Trung District, Hanoi, Vietnam
}

\begin{abstract}
From the leaf of the "O dau" plant growning in Ha Giang province, was extracted, analyzed, sequenced and compared with gene sequence samples of the species Aconitum genus. The result was the genomic sequence of "O dau" plant and compared to the genetic sequences of $A$. carmichaeli Debx. that there is a similarity to $99 \%$. Thus by method of DNA sequencing have identified the scientific name of the "O dau" plant growing in the Ha Giang province as Aconitum carmichaeli Debx.
\end{abstract}

Keywords: A. carmichaeli, DNA, sequencing. 